\title{
The supplementations with 2-hydroxyoleic acid and $n-3$ polyun- saturated fatty acids revert oxidative stress in various organs of diet-induced obese mice
}

\author{
C. HUNSCHE ET AL.
}

\author{
[AQ0]
Caroline Hunsche ${ }^{\mathrm{a}}$ Irene Martínez de Toda ${ }^{\mathrm{a}}$ Oskarina Hernandez ${ }^{\mathrm{a}}$ Beatriz Jiménez $^{\mathrm{a}}$ Ligia Esper- $^{-}$ anza Díaz ${ }^{\mathrm{b}}$ Ascensión Marcos ${ }^{\mathrm{b}}$ Mónica De la Fuente ${ }^{\mathrm{a}}$ \\ a. Department of Genetics, Physiology and Microbiology (Unit of Animal Physiology), Faculty of Biology, Complutense University \\ of Madrid and Research Institute of Hospital 12 de Octubre ( $i+12)$, Madrid, Spain; \\ $b$. Department of Metabolism and Nutrition, Institute of Food Science, Technology and Nutrition (ICTAN), Spanish National Re- \\ search Council (CSIC), Madrid, Spain [AQ1]
}

CONTACT Mónica De la Fuente mondelaf@bio.ucm.es Department of Genetics, Physiology and Microbiology (Unit of Animal Physiology), Faculty of Biology, Complutense University of Madrid, José Antonio Novais Street, 12, Madrid 28040, Spain

\begin{abstract}
Obesity and its related diseases have been associated with oxidative stress. Thus, the search for nutritional strategies to ameliorate oxidative stress in obese individuals seems important. We hypothesized that the supplementation with monounsaturated (2hydroxyoleic acid (2-OHOA)) and with combined n-3 polyunsaturated (eicosapentaenoic acid (EPA) and docosahexaenoic acid (DHA)) fatty acids would ameliorate oxidative stress in different organs, including brain, liver, lungs, and kidneys of adult dietinduced obese (DIO) mice. Adult female ICR-CD1 mice were fed a high-fat diet (HFD) for 14 weeks. During the last 6 weeks of HFD feeding, one group of DIO mice received the same HFD, supplemented with $1500 \mathrm{mg}$ of 2-OHOA per kg of HFD and another group with $1500 \mathrm{mg}$ of EPA and $1500 \mathrm{mg}$ of DHA per kg of HFD. At the end of the experiment, several parameters of oxidative stress were assessed. The supplementation with 2-OHOA or with EPA and DHA in DIO mice was able to revert oxidative stress, enhancing the activities of catalase and glutathione reductase, as well as diminishing the activity of xanthine oxidase, the concentration of thiobarbituric acid reactive substances (TBARS) and the ratio between oxidized glutathione and reduced glutathione in several organs. These reached similar values to those of control mice, which were fed a standard diet. These data suggest that supplementation with 2-OHOA and with EPA and DHA could be an effective nutritional intervention to restore an appropriate redox state in DIO mice.
\end{abstract}

Keywords: Diet-induced obese mice ;2-OHOA ; EPA and DHA ; oxidative stress ; organs

\section{FUNDING}

Ministry of Science and InnovationBFU2011-30336Research Group of Madrid Complutense University910379ENEROINNFISPI15/01787Carlos III Health Institute of the European Union (ISCIII-FEDER)PRONAOS StudyCDTI 20081114BTSA-Applied Biotechnologies S.L.This work was supported by grants from Ministry of Science and Innovation [BFU2011-30336], the Research Group of Madrid Complutense University [910379ENEROINN], FIS [PI15/01787] from the Carlos III Health Institute of the European Union (ISCIII-FEDER), the PRONAOS Study [CDTI 20081114], and BTSA-Applied Biotechnologies S.L.

\section{Introduction}


The high intake of fat and calories has been associated with the development and maintenance of obesity in both humans and rodents $[11,181$ Dbesity has become a global health problem and represents an important contributor to the current burden of chror $\equiv$ iseases [2]

Increasing evidence suggests that oxidative stress plays a critical role in the pathogenesis of obesity and its related diseases, such as type-2 diabetes, cardiovascular and neurodegenerative diseases [34] $\equiv$ possible causes of oxidative stress in obesity include hyperglycemia [45 undefined5] Eerleptinemia [56] $\equiv$ quate antioxidant defenses, increased free radical formation rates [67] $\equiv$ vated tissue $\sum_{1}$ amounts [undefir $\equiv$ paired mitochondria and

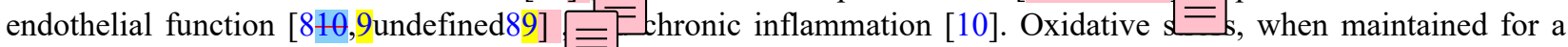
long period of time, can damage cellular $\$$ tures and trigger an inflammatory response, closing a detrimental feedback loop [1011,11]. At low/moderate concentrations, ROS are essential to regulate biological and physiological processes, such as several signaling pathways, gene expression, and apoptosis [1212]. However, at high concentrations, ROS lead to oxidative damage. Recent studies have shown that a lower capacity of antioxidant enzymes, such as catalase (CAT), glutathione peroxidase (Gpx), and reductase activities, as well as a higher production of oxidants (xanthine oxidase (XO) activity, glutathione redox ratio, and lipid peroxidation) could be considered markers of oxidative stress $[1013,1314,14]$. Similar to obesity, the process of aging has also been associated with oxidative stress [1515]. In fact, according to the oxidative-inflammatory theory of aging, the generation of chronic oxidative stress and inflammatory stress is the basis of the age-related impairment of the functions of the organism 15 . $\equiv$ have found that obesity results in premature features of aging in adult mice, such as oxidative stress and immunos ${ }_{\text {cence (i.e. age- }}$ related changes of the immune system). Therefore, obesity has been suggested as a possible model of premature and accelerated aging $[161617,17]$. In this sense, the search for strategies to ameliorate oxidative stress, and consequently to promote healthy aging in obese individuals seems important.

Previous studies confirmed that the high-fat diet (HFD) intake ( $60 \%$ of energy as fat) is a good model to produce obesity in mice $\left[\begin{array}{lllll}1322,222321 & 2320 & 2318 & 22,1717 & 22,\end{array}\right.$ creased adipose tissue, liver steatosis, insulin resistance, $\equiv$ oxidative stress in different tissues. Also, these animals exhibit a pro-inflammatory status $[1620,201923,23232224]$ Erestingly, this obesity model depletes the synthesis and levels of n-3 PUFA in different tissues, with an enhancem ${ }_{\text {in }}$ the n-6/n-3 PUFA ratio favoring a pro-inflammatory state $[25,25262426]$ this context, the diets rich in monounsaturated fatty acids (MUFA) from olive oil and in n-3 polyunsaturated fatt 三ids (PUFA), namely eicosapentaenoic acid (EPA) and docosahexaenoic acid (DHA), from marine-based fish oil and fish, promote beneficial effects for obesity and related diseases [22626] $\equiv \mathrm{e}$ of the possible mechanisms involved in these effects could be the incorporation of unsaturated fatty acids into th 11 membranes, which occurs in all tissues of the body, following their consumption. In addition, these fatty acids are known to modulate cell functions, by modifying membrane fluidity, lipid peroxide formation, eicosanoid production, and gene regulation [2727,2828] Eerging evidence indicates that the supplementations with 2-hydroxyoleic acid (2OHOA), a synthetic derivativ $\equiv$ MUFA oleic acid, and with EPA and DHA ameliorate the cardiometabolic risk and revert the altered redox state and functions in immune cells of DIO mice 1329. $\equiv$ ever, the specific role these unsaturated fatty acids on the oxidative stress of non-immune organs remains un $\equiv$ vn. Therefore, the aim of this study was to evaluate several oxidative stress parameters in the brain, liver, lungs, and kidneys of DIO mice supplemented with 2-OHOA or with the combination of n-3 fatty acids (EPA and DHA).

\section{Materials and methods}

\section{Animals}

Female ICR/CD1 mice, 8 weeks of age, were purchased from Harlan Interfauna Iberica (Barcelona, Spain). For the first five days of acclimatization to a new environment, all mice were fed a standard maintenance diet (Teklad Global 14\%). The animals were housed in polyurethane cages (two animals per cage) and maintained at a constant temperature of $22 \pm 2{ }^{\circ} \mathrm{C}$, with adequate ventilation and relative humidity of $50-60 \%$ on a $12 / 12 \mathrm{~h}$ reversed light/dark cycle (lights on at 8:00 pm). The experiments procedures and handling of animals were performed with approval of the Committee for Animal Experimentation of the Complutense University of Madrid (ref. CEA-UCM 06/2012) and were conducted in accordance with the guidelines and protocols of the Royal Decree 53/2013 regarding the care and use of laboratory animals. 


\section{Experimental groups}

The animals, at 9 weeks of age, were separated into four groups ( $n=8$, per group). (1) The control mice group (C) were fed a standard maintenance diet until the end of the study. (2) The DIO mice group were fed an HFD $(60 \%$ of calories from fat, reference TD. 06414, Harlan Interfauna Iberica) for 14 weeks. (3) The 2-OHOA-supplemented DIO (2-OHOA-DIO) mice group were fed a HFD for 14 weeks, but received during the last 6 weeks of HFD, the supplementation with 2-OHOA (1500 mg of 2-OHOA per kg of HFD, BTSA-Applied Biotechnologies S.L., Bedford, MA). (4) The EPA and DHA-supplemented DIO mice group (EPA and DHA-DIO) were fed a HFD for 14 weeks, this being supplemented during the last 6 weeks with the combination of EPA and DHA (1500 mg of EPA and $1500 \mathrm{mg}$ DHA per kg of HFD, BTSA-Applied Biotechnologies S.L., Bedford, MA). In order to progressively increase the amount of fat in the diet of groups 2, 3, and 4, the animals were fed with an intermediate-fat diet (IFD, $22 \%$ of calories from fat, Teklad Global 2019, Harlan Interfauna Iberica) for 4 weeks prior to the ingestion of HFD. The 2-OHOA is a synthetic derivative of oleic acid, and it is also known as 2-hydroxy-D9-cis-octadecenoic acid. The n-3 PUFA were extracted from fish (anchovy). The supplements 2-OHOA as well as EPA and DHA were provided in powdered form and in oil form, respectively, and were mixed into the chow, which was of malleable consistency. After the chow was uniformly mixed, it was made into pellets. The 2-OHOA and the combined EPA and DHA supplementation doses were chosen according to a previous study, in which the same supplemented doses were associated with changes in the gut microbiota of DIO mice [2929] $\equiv$ roughout the entire study, all mice were given ad libitum

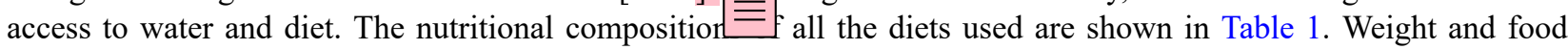
intake were measured every week from the start to the end of the study.

Table 1. Composition of the diets.

\begin{tabular}{|c|c|c|c|c|c|}
\hline Components & $\begin{array}{l}\text { Standard mainte- } \\
\text { nance diet }\end{array}$ & $\begin{array}{l}\text { Intermediate- } \\
\text { fat diet }\end{array}$ & High-fat diet & $\begin{array}{l}\text { High-fat diet }+2- \\
\text { OHOA supplemen- } \\
\text { tation }\end{array}$ & $\begin{array}{l}\text { High-fat diet }+ \\
\text { EPA and DHA } \\
\text { supplementation }\end{array}$ \\
\hline Energy (kcal/g) & 2.9 & 3.3 & 5.1 & 5.1 & 5.1 \\
\hline Protein $(\%)$ & 14.3 & 19.0 & 23.5 & 23.5 & 23.5 \\
\hline Carbohydrate (\%) & 48.0 & 44.9 & 27.3 & 27.3 & 27.3 \\
\hline Fat (\%) & 4.0 & 9.0 & 34.3 & 34.4 & 34.6 \\
\hline Saturated (\%) & 0.6 & 1.2 & 12.5 & 12.5 & 12.5 \\
\hline Monounsaturated (\%) & 0.7 & 1.7 & 16.1 & 16.2 & 16.1 \\
\hline Polyunsaturated (\%) & 2.1 & 4.4 & 5.4 & 5.4 & 5.7 \\
\hline Protein (\% of energy) & 20.0 & 23.0 & 18.4 & 18.4 & 18.3 \\
\hline Carbohydrate ( $\%$ of energy) & 67.0 & 55.0 & 21.3 & 21.3 & 21.2 \\
\hline Fat (\% of energy) & 13.0 & 22.0 & 60.3 & 60.4 & 60.5 \\
\hline \multicolumn{6}{|l|}{ Fatty acid composition (\%) } \\
\hline 16:0 palmitic & 0.5 & 0.9 & 8.2 & 8.2 & 8.2 \\
\hline 18:0 stearic & 0.1 & 0.2 & 3.9 & 3.9 & 3.9 \\
\hline 18:1n-9 oleic & 0.7 & 1.7 & 14.7 & 14.8 & 14.7 \\
\hline 18:2n-6 linoleic & 2.0 & 3.9 & 4.7 & 4.7 & 4.7 \\
\hline 18:3n-3 linolenic & 0.1 & 0.4 & 0.5 & 0.5 & 0.8 \\
\hline n-6:n-3 ratio & $20: 1$ & $10: 1$ & $9: 1$ & $9: 1$ & $6: 1$ \\
\hline
\end{tabular}

\section{Collection of organs}

Animals were euthanized at 8:00 am by decapitation, and no anesthetic was used to avoid the effect of anesthesia on the results. Organs were extracted post-mortem immediately and washed carefully with phosphate buffer, $\mathrm{pH} 7.4$. The brain, liver, lungs, and kidneys were frozen in liquid nitrogen and stored at $-80^{\circ} \mathrm{C}$ until performing the oxidative stress assays. 


\section{Catalase activity assay}

The activity of CAT was determined following the method previously described [3032]. The assays were performed using aliquots of the homogenized tissue samples $(50 \mathrm{mg} / \mathrm{ml}$, for kidneys and lungs, and $25 \mathrm{mg} / \mathrm{ml}$, for liver) in phosphate buffer $(66 \mathrm{mM}, \mathrm{pH} 8.4)$ and centrifuged at $3200 \times \mathrm{g}$ for $20 \mathrm{~min}$ at $4{ }^{\circ} \mathrm{C}$. The supernatant extract $(30 \mu \mathrm{l})$ was mixed with $670 \mu \mathrm{l}$ of hydrogen peroxide $\left(\mathrm{H}_{2} \mathrm{O}_{2}\right)\left(14 \mathrm{mM}\right.$ of $\mathrm{H}_{2} \mathrm{O}_{2}$ in phosphate buffer) (Merck, Darmstadt, Germany). The enzymatic assay was followed using spectrophotometry for $80 \mathrm{~s}$ at $240 \mathrm{~nm}$ through the decomposition of $\mathrm{H}_{2} \mathrm{O}_{2}$ into $\mathrm{H}_{2} \mathrm{O}+\mathrm{O}_{2}$. Protein content of the samples was assessed following the bicinchoninic acid (BCA) protein assay kit protocol (Sigma-Aldrich, Madrid, Spain). The results were expressed as units (U) of enzymatic activity per milligram of protein (U CAT/mg protein).

\section{Glutathione peroxidase activity assay}

The Gpx activity was determined according to the method previously described 32 . $\equiv$ assays were performed with aliquots of the homogenate tissue samples $(50 \mathrm{mg} / \mathrm{ml}$, for brain, kidneys and lungs, $25 \mathrm{mg} / \mathrm{ml}$ for liver) in phosphate buffer $(50 \mathrm{mM}, \mathrm{pH} 7.4)$ and centrifuged at $3200 \times \mathrm{g}$ for $20 \mathrm{~min}$ at $4{ }^{\circ} \mathrm{C}$. The total activity was determined using cumene hydroperoxide (Sigma-Aldrich, Madrid, Spain), which carried out the oxidation of $\beta$-nicotinamide adenine dinucleotide phosphate, in its reduced form ( $\beta$-NADPH, Sigma-Aldrich, Madrid, Spain), in the presence of glutathione reductase (GR) (Sigma-Aldrich, Madrid, Spain). The reaction was measured spectrophotometrically by the decrease of the absorbance at $340 \mathrm{~nm}$. The protein contents were evaluated following the previously mentioned protocol. The results were expressed as milliunits of enzymatic activity per milligram of proteins (mU GPx/mg protein).

\section{Glutathione reductase activity assay}

The GR activity was measured by the technique previously described 32. $\equiv$ assays were performed with aliquots of the homogenate tissue samples $\left(50 \mathrm{mg} / \mathrm{ml}\right.$, for kidneys and lungs, and $25 \equiv_{\mathrm{ml}}$ for liver) in phosphate buffer 50 $\mathrm{mM}$, pH 7.4 with $6.3 \mathrm{mM}$ ethylenediaminetetraacetic acid (EDTA), and centrifuged at $3200 \times \mathrm{g}$ for $20 \mathrm{~min}$ at $4{ }^{\circ} \mathrm{C}$. The total activity was measured through the oxidation of NADPH spectrophotometrically at $340 \mathrm{~nm}$. The protein contents of samples were evaluated following the previously described protocol. The results were expressed as milliunits of enzymatic activity per milligram of proteins ( $\mathrm{mU} \mathrm{GR} / \mathrm{mg}$ protein).

\section{Glutathione concentrations assay}

Both reduced (GSH) and oxidized (GSSG) concentrations of glutathione were measured using a fluorometric method. This method is based on the reaction of a fluorescence probe, o-phthaldialdehyde (OPT; Sigma-Aldrich, Madrid, Spain), with GSH at pH 8 and with GSSG at pH 12, which generates a fluorescence derivative. The tissue samples were homogenized ( $50 \mathrm{mg} / \mathrm{ml}$, for kidneys and lungs, and $25 \mathrm{mg} / \mathrm{ml}$ for liver) in sodium phosphate-EDTA buffer $(0.1 \mathrm{M}, \mathrm{pH})$ and proteins were precipitated by adding $5 \mu \mathrm{l}$ of $60 \%$ perchloric acid $\left(\mathrm{HClO}_{4}\right)(60 \%$, Sigma-Aldrich, Madrid, Spain). The homogenate tissue samples were centrifuged at $9500 \times \mathrm{g}$ for $10 \mathrm{~min}$ at $4{ }^{\circ} \mathrm{C}$ and supernatants were maintained in ice for the measurement of GSH and GSSG concentrations. For GSH content determination, $10 \mu$ of the supernatant, $190 \mu \mathrm{l}$ of phosphate-EDTA buffer, and $20 \mu \mathrm{l}$ of OPT solution $(1 \mathrm{mg} / \mathrm{ml}$ in methanol) were added to a 96-well black plate (Nunc, Roskilde, Denmark), and incubated at room temperature for 15 min. Fluorescence was determined in a plate reader (Fluostar Optima, BMG Labtech, Barcelona, Spain) using excitation at $350 \mathrm{~nm}$ and emission detection at $420 \mathrm{~nm}$. For the measurement of GSSG contents, $8 \mu 1$ of N-ethylmaleimide (NEM, $0.04 \mathrm{M}$, SigmaAldrich, Madrid, Spain) were added to each well and incubated at room temperature for $30 \mathrm{~min}$. Then, $182 \mu 1$ of sodium hydroxide $(\mathrm{NaOH})(0.1 \mathrm{~N}$, Panreac Quimica SA, Barcelona, Spain) with $20 \mu \mathrm{l}$ of OPT solution were added to a 96-well black plate. After incubation (room temperature, $15 \mathrm{~min}$ ), fluorescence was measured as previously described for GSH determination. Protein concentration of the samples was measured following the BCA protein assay kit protocol (Sigma-Aldrich, Madrid, Spain). The results were analyzed with GSH and GSSG standard curves at different concentrations and expressed as nmol/mg protein. The GSSG/GSH ratios were then calculated for each sample.

\section{Xanthine oxidase activity assay}


Xanthine oxidase activity was measured, by a fluorescence assay, in homogenates of tissues, using a commercial kit (Amplex Red Xanthine/Xanthine Oxidase Assay Kit, Molecular Probes, Paisley, UK). The $\mathrm{H}_{2} \mathrm{O}_{2}$ produced by XO reacts with the horseradish peroxidase (HRP) present in the reaction mixture and generates a fluorescent oxidation compound resorufin whose fluorescence is measured in a plate reader (Fluorestar Optima, BMG Labtech Biomedal, Seville, Spain). Tissue samples were homogenized $(50 \mathrm{mg} / \mathrm{ml}$, for kidneys and lungs, and $25 \mathrm{mg} / \mathrm{ml}$ for liver) in phosphate buffer $(50 \mathrm{mM}, \mathrm{pH} 7.4)$ containing $1 \mathrm{mM}$ EDTA. The homogenate was centrifuged $(5000 \times g)$, and the supernatant $(50 \mu \mathrm{l})$ was collected and incubated with $50 \mu \mathrm{l}$ working solution of Amplex Red reagent $(100 \mu \mathrm{M})$ containing $\mathrm{HRP}(0.4 \mathrm{U} / \mathrm{ml})$ and xanthine $(200 \mu \mathrm{M})$. After $30 \mathrm{~min}$ of incubation at $37^{\circ} \mathrm{C}$, measurement of fluorescence was performed in the microplater reader, using excitation at $530 \mathrm{~nm}$ and emission detection at $595 \mathrm{~nm}$. XO supplied in the kit was used as the standard. Protein content of the samples was assessed using the BCA protein assay (Sigma-Aldrich, Madrid, Spain). The results were expressed as milliunits of enzymatic activity per milligram of protein (mU XO/mg protein).

\section{Lipid peroxidation (thiobarbituric acid reactive substances (TBARS) assay)}

Lipid peroxidation was evaluated using a colorimetric assay kit (BioVision, Mountain View, CA), which measures the reaction of MDA with thiobarbituric acid (TBA) and the MDA-TBA adduct formation. The tissue samples were homogenized ( $50 \mathrm{mg} / \mathrm{ml}$, for brain, kidneys, and lungs, and $25 \mathrm{mg} / \mathrm{ml}$ for liver) in $300 \mu$ of MDA lysis buffer with 3 $\mu \mathrm{l}$ butylhydroxytoluene $(\mathrm{BHT})(\times 100)$ and then centrifuged $\left(13,000 \times \mathrm{g}, 10 \mathrm{~min}, 4^{\circ} \mathrm{C}\right)$ to remove insoluble material. An aliquot $(200 \mu \mathrm{l})$ of each supernatant was added to $600 \mu \mathrm{l}$ of TBA and incubated at $95^{\circ} \mathrm{C}$ for $60 \mathrm{~min}$. The samples were then maintained in an ice bath for $10 \mathrm{~min}$ and $200 \mu \mathrm{l}$ from each $800 \mu \mathrm{l}$ reaction mixture were placed into a 96 well microplate for spectrophotometric measurement at $532 \mathrm{~nm}$. Protein concentration was measured following the BCA protein assay kit (Sigma-Aldrich, Madrid, Spain). The results were obtained using a TBARS standard curve at different concentrations and expressed as nmol TBARS/mg protein.

\section{Statistical analysis}

The statistical analysis of results was performed in SPSS IBM, version 25.0 (SPSS, Inc., Chicago, IL). The data were expressed as mean \pm standard error of the mean (SEM). Each value is the mean of the data from an assay performed in duplicate or triplicate. The normality of the samples was checked by the Kolmogorov-Smirnov test and homogeneity of variances with the Levene test. The data were statistically evaluated by one-way ANOVA followed by Tukey's post hoc test for homogenous variances. Games-Howell's post hoc test was used for unequal variances. $p$ $<.05$ was considered statistically significant.

\section{Results}

\section{Body weight and food intake}

As shown in Table 2, body weight and food intake at the beginning of the study (9 weeks of age) were similar among the experimental groups. At the end of the study (27 weeks of age), body weight and food intake were significantly increased in DIO mice in comparison with controls $(p=.02$ and $p=.004$, respectively; Table 2). In addition, DIO mice supplemented with 2-OHOA significantly decreased their body weight when compared with DIO mice ( $p$ $=.006$; Table 2).

Table 2. Average body weight and food intake.

\begin{tabular}{|c|c|c|c|c|}
\hline & Control & DIO mice & 2-OHOA-DIO mice & EPA and DHA-DIO mice \\
\hline Average initial weight (g) (9 weeks) & $27 \pm 0.5$ & $28 \pm 0.5$ & $26 \pm 0.7$ & $26 \pm 0.5$ \\
\hline Average final weight (g) (27 weeks) & $34 \pm 1.2$ & $51 \pm 4.2 *$ & $28 \pm 1.3 \# \#$ & $48 \pm 4.4$ \\
\hline $\begin{array}{l}\text { Average initial food intake (kcal/mouse/day) (9 } \\
\text { weeks) }\end{array}$ & $11 \pm 0.03$ & $11 \pm 0.3$ & $11 \pm 0.2$ & $11 \pm 0.2$ \\
\hline $\begin{array}{l}\text { Average final food intake (kcal/mouse/day) (27 } \\
\text { weeks) }\end{array}$ & $13 \pm 0.5$ & $17 \pm 0.8 * *$ & $15 \pm 1$ & $17 \pm 1$ \\
\hline
\end{tabular}


DIO: diet-induced obese; 2-OHOA-DIO: 2-hydroxyoleic acid supplemented DIO; EPA and DHA-DIO: eicosapentaenoic acid and docosahexaenoic acid supplemented DIO.

Each value represents the mean \pm SEM of the data weekly for the period indicated corresponding to 8 animals.

${ }^{*} p<.05$ with respect to the values in non-obese control mice.

${ }^{* *} p<.01$ with respect to the values in non-obese control mice.

$\#^{\prime} p<.01$ with respect to the values in DIO mice.

\section{Left and right cerebral cortex and hypothalamus}

The GPx and GR activities, two antioxidant enzymes of the glutathione system, were significantly lower in the left $(p<.001$; Figure 1(A)) and right cerebral cortex $(p=.026$; Figure 1(B)), respectively, of DIO mice as compared with non-DIO controls. However, DIO mice that were supplemented with 2-OHOA or with EPA and DHA showed significantly higher activity of these enzymes in comparison with DIO mice $(p=.03$ and $p<.001$ for GPx activity, respectively; Figure 1(A)) and ( $p=.04$ and $p=.01$ for GR activity, respectively; Figure 1(B)).

Figure 1. Oxidative stress parameters in the brain. (A) Left cerebral cortex glutathione peroxidase (GPx) activity (mU/mg protein). (B) Right cerebral cortex glutathione reductase (GR) activity (mU/mg protein). (C) Hypothalamic thiobarbituric acid reactive substances (TBARS) concentration (nmol/mg protein). Each column represents the mean \pm SEM of 8 values corresponding to that number of animals and each value being the mean of duplicate or triplicate assays. ${ }^{* *} p<.001 ;{ }^{*} p<.05$ with respect to the values

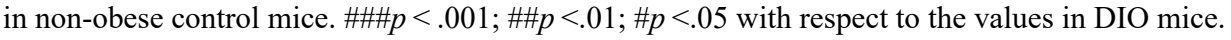

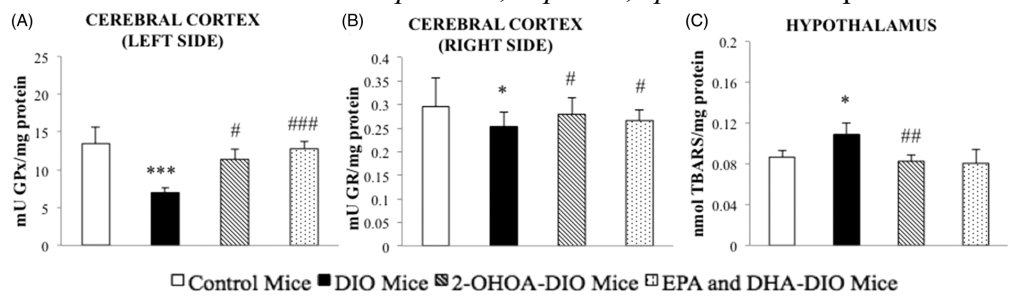

The TBARS concentration, which is an indicator of lipid oxidation and oxidative damage in cells, was significantly higher in the hypothalamus of DIO mice with respect to non-DIO mice $(p=.04$; Figure $1(\mathrm{C}))$. In turn, the supplementation with 2-OHOA was able to lower the concentration of TBARS in comparison with non-supplemented DIO mice $(p=.009$; Figure $1(\mathrm{C}))$. No significant differences were observed between EPA and DHA-DIO supplemented and non-supplemented mice regarding the concentration of TBARS in the hypothalamus $(p=.4$; Figure $1(\mathrm{C}))$.

\section{Liver}

The antioxidant CAT and GR activities were significantly lower in the liver of DIO mice as compared with that in non-DIO controls ( $p=.008$ and $p=.012$, respectively; Figure 2(A,C)). By contrast, the GPx activity was significantly higher in DIO mice than in their respective non-DIO controls $(p=.015$; Figure $2(\mathrm{~B}))$. The supplementation with 2OHOA or with EPA and DHA resulted in significantly higher CAT activity in the liver $(p=.015$ and $p<.001$, respectively; Figure 2(A)) in comparison with non-supplemented DIO mice. In addition, the supplementation with EPA and DHA resulted in lower activity of GPx and higher activity of GR in the liver of DIO mice $(p<.001$ and $p=.038$, respectively; Figure $2(\mathrm{~B}, \mathrm{C})$ ) than in non-supplemented DIO mice. No statistically significant differences were observed in the activities of GPx and GR in the liver of 2-OHOA-DIO mice and non-supplemented DIO mice $(p=.073$ and $p=.108$, respectively; Figure 2(B,C)).

Figure 2. Oxidative stress parameters in the liver. (A) Hepatic catalase (CAT) activity (U/mg protein). (B) Hepatic glutathione peroxidase (GPx) activity (mU/mg protein). (C) Hepatic glutathione reductase (GR) activity (mU/mg protein). (D) Hepatic xanthine oxidase (XO) activity (mU/mg protein). (E) Hepatic oxidized glutathione (GSSG)/reduced glutathione $(\mathrm{GSH})$ ratio $\left(\times 10^{-2}\right)$. (F) Hepatic thiobarbituric acid reactive substances (TBARS) concentration. Each column represents the mean \pm SEM of 8 values corresponding to that number of animals and each value being the mean of duplicate or triplicate assays. ${ }^{* * *} p<.001 ;{ }^{* *} p<.01$;

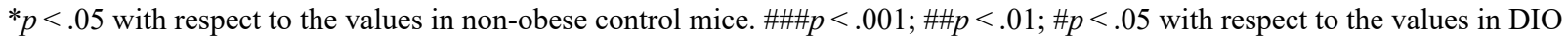
mice. 


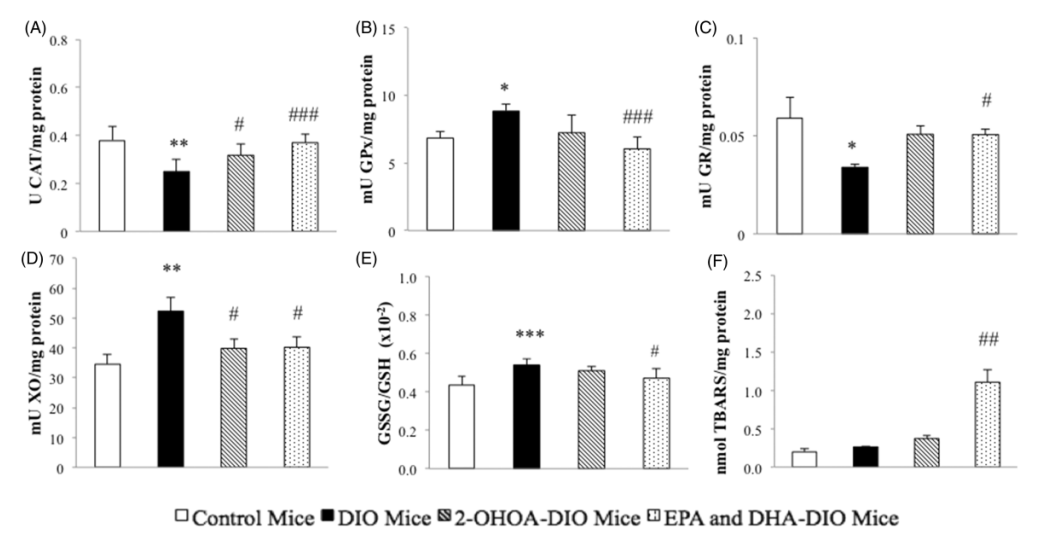

The activity of $\mathrm{XO}$, which is associated with the production of free radicals, as well as the GSSG/GSH ratio, an indicator of oxidative stress, was significantly higher in DIO mice in comparison with those in non-DIO controls ( $p$ $=.001$ and $p<.001$, respectively; Figure 2(D,E)). No statistically significant differences were observed in the concentration of TBARS in the liver of DIO mice and non-DIO mice $(p=.564$; Figure $2(\mathrm{~F}))$. The supplementation with 2OHOA or with EPA and DHA resulted in significantly lower XO activity in the liver $(p=.028$ and $p=.032$, respectively; Figure 2(D)) in comparison with non-supplemented DIO mice. In addition, the supplementation with EPA and DHA resulted in lower GSSG/GSH ratios and higher TBARS concentration in the liver of DIO mice $(p=.017$ and $p$ $=.006$, respectively; Figure 2(E,F)) than in non-supplemented DIO mice. No statistically significant differences were observed in the GSSG/GSH ratios and TBARS concentration in the liver of 2-OHOA-DIO mice and non-supplemented DIO mice $(p=.510$ and $p=.079$, respectively; Figure 2(E,F)).

\section{Lungs}

The activities of CAT and GR were significantly lower in the lungs of DIO mice than in non-DIO controls ( $p$ $<.001$ and $p<.001$, respectively; Figure $3(\mathrm{~A}, \mathrm{C})$ ). However, the GPx activity was significantly higher in DIO mice than in their respective non-DIO controls $(p<.001$; Figure 3(B)). The supplementation with 2-OHOA or with EPA and DHA in DIO mice resulted in significantly lower activity of GPx $(p<.001$ and $p<.001$, respectively; Figure $3(\mathrm{~B}))$ and higher activity of GR $(p=.001$ and $p=.001$, respectively; Figure 3(C)) with respect to non-supplemented DIO mice. In addition, the supplementation with EPA and DHA in DIO mice resulted in significantly higher CAT activity $(p<.001$; Figure 3(A)) than in non-supplemented DIO mice. No statistically significant differences were observed in the CAT activity in the lungs of 2-OHOA-DIO mice and non-supplemented DIO mice $(p=.062$; Figure 3(A)).

Figure 3. Oxidative stress parameters in the lungs. (A) Lungs catalase (CAT) activity (U/mg protein). (B) Lungs glutathione peroxidase (GPx) activity (mU/mg protein). (C) Lungs glutathione reductase (GR) activity (mU/mg protein). (D) Lungs xanthine oxidase (XO) activity (mU/mg protein). (E) Lungs oxidized glutathione (GSSG)/reduced glutathione $(\mathrm{GSH})$ ratio $\left(\times 10^{-2}\right)$. $(\mathrm{F}) \mathrm{Lungs}$ thiobarbituric acid reactive substances (TBARS) concentration. Each column represents the mean $\pm \mathrm{SEM}$ of 8 values corresponding to that number of animals and each value being the mean of duplicate or triplicate assays. $* * * p<.001$ with respect to the

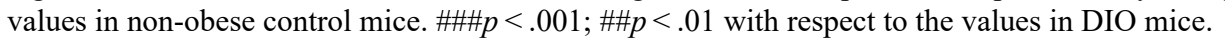



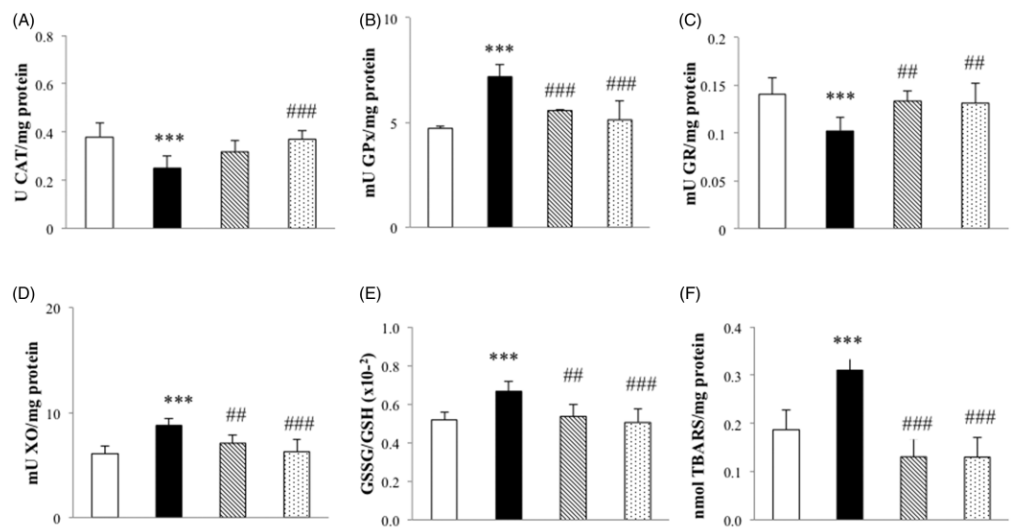

$\square$ Control Mice $\square$ DIO Mice $\$ 2-O H O A-D I O$ Mice ${ }^{\mathbb{E}}$ EPA and DHA-DIO Mice

The XO activity, GSSG/GSH ratios, and TBARS concentration were significantly higher in DIO mice than in nonDIO controls $(p<.001, p<.001$, and $p<.001$, respectively; Figure 3(D-F)). The supplementation with 2-OHOA or with EPA and DHA resulted in significantly lower XO activity $(p=.005$ and $p<.001$, respectively; Figure 3(D)), GSSG/GSH ratios $(p=.002$ and $p<.001$, respectively; Figure 3(E)), and TBARS concentration $(p<.001$ and $p$ $<.001$, respectively; Figure $3(\mathrm{~F})$ ) in the lungs of DIO mice in comparison with non-supplemented DIO mice.

\section{Kidneys: renal medulla and cortex}

The activities of CAT and GR were significantly lower in the renal medulla of DIO mice in comparison with nonDIO controls $(p=.001$ and $p=.006$, respectively; Figure 4(A,C)). By contrast, the GPx activity was significantly higher in DIO mice than in their respective non-DIO controls $(p=.025$; Figure $4(\mathrm{~B}))$. The supplementation with 2OHOA or with EPA and DHA resulted in significantly higher activity of CAT $(p=.001$ and $p<.001$, respectively; Figure 4(A)) and lower activity of GPx $(p=.024$ and $p=.015$, respectively; Figure 4(B)) in the renal medulla of DIO mice in comparison with non-supplemented animals. In addition, the supplementation with 2-OHOA resulted in significantly higher GR activity $(p=.022$; Figure $4(\mathrm{C})$ ) in the renal medulla of DIO mice in comparison with non-supplemented DIO mice. No statistically significant differences were observed in the GR activity in the renal medulla of EPA and DHA-supplemented DIO mice and non-supplemented DIO mice $(p=.995$; Figure 4(C)).

Figure 4. Oxidative stress parameters in the renal medulla. (A) Renal medulla catalase (CAT) activity (U/mg protein). (B) Renal medulla glutathione peroxidase (GPx) activity (mU/mg protein). (C) Renal medulla glutathione reductase (GR) activity (mU/mg protein). (D) Renal medulla xanthine oxidase (XO) activity (mU/mg protein). (E) Renal medulla oxidized glutathione (GSSG)/

reduced glutathione $(\mathrm{GSH})$ ratio $\left(\times 10^{-2}\right)$. (F) Renal medulla thiobarbituric acid reactive substances (TBARS) concentration. Each column represents the mean \pm SEM of 8 values corresponding to that number of animals and each value being the mean of duplicate or triplicate assays. ${ }^{* * *} p<.001 ;{ }^{* *} p<.01 ;{ }^{*} p<.05$ with respect to the values in non-obese control mice. \#\#\#p<.001;\#\#p $<.01 ; \# p<.05$ with respect to the values in DIO mice.
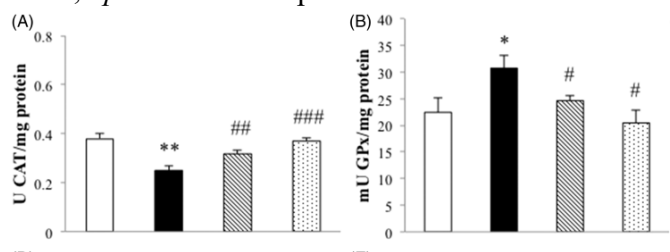

(C)

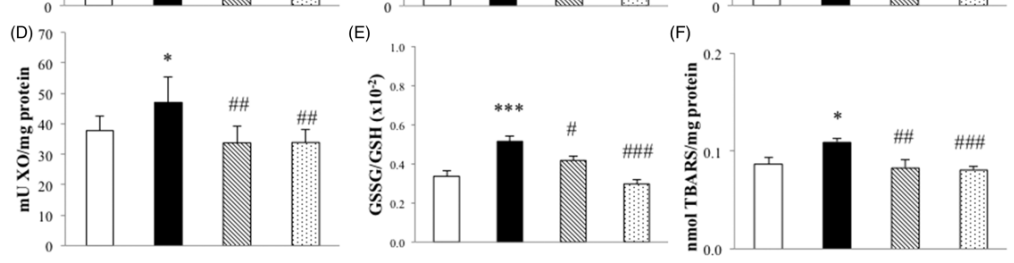

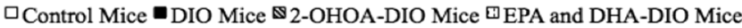


The XO activity, GSSG/GSH ratios, and TBARS concentration were significantly higher in DIO mice than in nonDIO controls $(p=.032, p<.001$, and $p=.034$, respectively; Figure 4(D-F)). The supplementation with 2-OHOA or with EPA and DHA resulted in significantly lower XO activity $(p=.003$ and $p=.003$, respectively; Figure 4(D)), GSSG/GSH ratios $(p=.015$ and $p<.001$, respectively; Figure 4(E)), and TBARS concentration $(p=.001$ and $p$ $<.001$, respectively; Figure $4(\mathrm{~F}))$ in the renal medulla of DIO mice than in non-supplemented animals.

The activities of CAT and GR were significantly lower in the renal cortex of DIO mice than in non-DIO controls $(p=.020$ and $p<.001$, respectively; Figure 5(A,C)). However, the GPx activity was significantly higher in DIO mice than in their respective non-DIO controls $(p<.001$; Figure 5(B)). The supplementation with 2-OHOA or with EPA and DHA resulted in significantly higher activities of CAT ( $p=.039$ and $p=.011$, respectively; Figure 5(A)) and GR $(p=.003$ and $p=.007$, respectively; Figure 5(C)) in the renal cortex of DIO mice in comparison with non-supplemented animals. The activity of GPx was significantly lower after the supplementation with 2-OHOA or with EPA and DHA $(p=.006$ and $p=.039$, respectively; Figure 5(B)) in the renal cortex of DIO animals in comparison with nonsupplemented DIO mice.

Figure 5. Oxidative stress parameters in the renal cortex. (A) Renal cortex catalase (CAT) activity (U/mg protein). (B) Renal cortex glutathione peroxidase (GPx) activity (mU/mg protein). (C) Renal cortex glutathione reductase (GR) activity (mU/mg protein). (D) Renal cortex xanthine oxidase (XO) activity (mU/mg protein). (E) Renal cortex oxidized glutathione (GSSG)/reduced glutathione $(\mathrm{GSH})$ ratio $\left(\times 10^{-2}\right)$. (F) Renal cortex thiobarbituric acid reactive substances (TBARS) concentration. Each column represents the mean \pm SEM of 8 values corresponding to that number of animals and each value being the mean of duplicate or triplicate

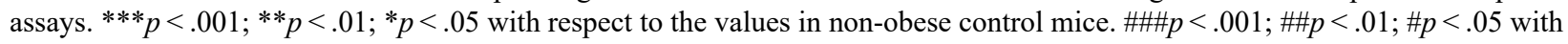
respect to the values in DIO mice.

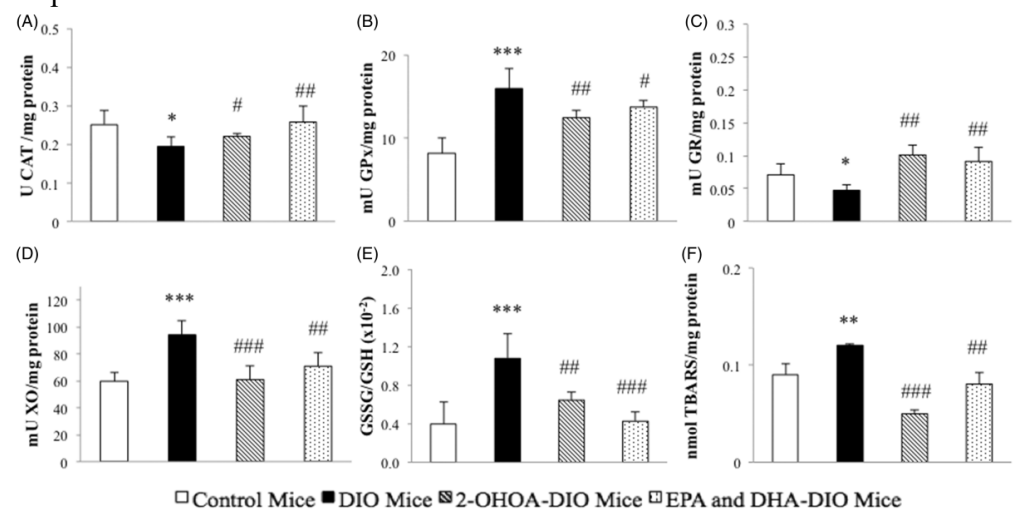

The XO activity, GSSG/GSH ratios, and TBARS concentration were significantly higher in DIO mice than in nonDIO controls $(p<.001, p=.001$, and $p=.002$, respectively; Figure 5(D-F)). The supplementation with 2-OHOA or with EPA and DHA resulted in significantly lower XO activity $(p<.001$ and $p=.001$, respectively; Figure 5(D)), GSSG/GSH ratios $(p=.013$ and $p=.001$, respectively; Figure 5(E)), and TBARS concentration $(p<.001$ and $p$ $=.002$, respectively; Figure $5(\mathrm{~F}))$ in the renal cortex of DIO mice in comparison with non-supplemented DIO animals.

\section{Discussion}

Although we previously demonstrated that the supplementations with 2-OHOA as well as with DHA and EPA improved the functions and redox state of immune cells $\equiv$, the effect of these supplementations on the oxidative stress of the brain, liver, lungs, and kidneys from DIO mL,

Our results showed that the mice fed an HFD gained significantly more body weight than controls (fed a standard diet). Previous studies from our laboratory confirmed that the HFD intake promotes obesity in ICR-CD1 mice. Additionally, these DIO mice show common features of obesity, such as elevated levels of triglycerides, total cholesterol, and systolic arterial pressure [1316171816 1821] $\equiv$ turn, we observed that the supplementation with 2-OHOA, but not with EPA and DHA, resulted in significantly ld ted high-fat fed animals. In this sense, 2-OHOA seems to promote body weight loss through the induction of uncoupling protein-1 (UCP-1) expression in the adipose tissue, a process probably accompanied by enhanced energy expenditure [3131] $\equiv$ contrast, the supplementation with EPA and DHA seems to not affect the body weight of obese 
individuals [3234]. A recent study from our laboratory showed that the supplementation with 2-OHOA reduces blood pressure, triglycerides, and leptin, and improves adiponectin and resistin secretion, while EPA and DHA only reduce triglyceride levels 21 .

Our current results demonstrated increased oxidative stress in the liver, lungs, and kidneys (renal medulla and cortex) of DIO mice in comparison with non-DIO controls. Thus, these DIO animals displayed lower antioxidant defenses, such as CAT and GR activities, as well as a higher production of oxidants, including XO activity, GSSG/GSH ratio, and lipid peroxidation (TBARS concentration) than non-DIO mice. In addition, we found diminished antioxidant defenses (i.e. GPx and GR activities) in the cerebral cortex and elevated TBARS concentration in the hypothalamus of DIO mice. The altered redox state seems to be associated with lipotoxicity in these organs, which is generated when triglycerides are inappropriately stored in non-adipose tissues. The excessive accumulation of intracellular triglycerides is known to reduce the efficacy of the electron transport chain, causing the release of ROS and the generation of oxidative damage 27. $\equiv$ greement with our current findings, previous reports also indicate that obesity in-

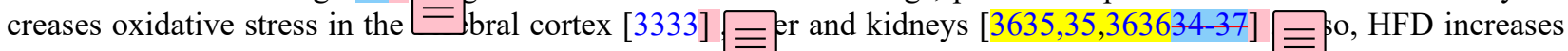
mitochondrial $\mathrm{H}_{2} \mathrm{O}_{2}$ production, causing the abnorma studies suggest that oxidative stress is related to adiposity, lipotoxicity, mitochondrial dysfunction, and endoplasmic reticulum stress in a variety of organs from obese rodents [20373836 3835 38 ] $\equiv$ addition, these alterations are accompanied by the inhibition of the expression and activity of the nuclear factor $=$ throid 2-related factor (Nrf2), which is a key transcription factor involved in the regulation of antioxidant defenses 2023. $\equiv$ estingly, we found higher values of GPx activity (an antioxidant enzyme) in the liver, lungs, and kidneys of DL hice in comparison with non-DIO mice. However, lower values of GPx activity were observed in the brain (right cerebral cortex) of DIO mice in comparison with non-DIO mice. The higher activity of this antioxidant enzyme could possibly be explained as a compensatory mechanism to protect these cells against oxidative damage [7] $\equiv$ nilarly, another study from our laboratory also found increased values of GPx in peritoneal leukocytes of DIO 1 . 17 . $\equiv$, the activity of this enzyme has been reported to increase or decrease in response to oxidative damage depend evolution and the amount of peroxides generated [3941,4141]

In turn, the dietary supplementations with 2-OHOA or with the combination of EPA and DHA in general were able to restore oxidative stress in the liver, lungs, and kidneys of DIO mice (with higher values of CAT and GR activities and lower values of XO activity, GSSG/GSH ratio, and TBARS concentration) in comparison with non-supplemented DIO mice. In addition, these supplementations led to higher values of GPx and GR activities in the cerebral cortex and lower values of TBARS in the hypothalamus of DIO mice when compared with non-supplemented DIO animals. In all cases, the values showed similar levels to those of non-DIO controls. Similarly, our recent studies in spleen and peritoneal immune cells also ameliorated oxidative stress after the supplementations with 2-OHOA or n-3 PUFA (EPA and DHA) (with increased values of CAT activity and total glutathione concentration and decreased values of XO activity, GSSG/GSH ratio, and TBARS concentration) $\equiv 918$. These results are also in agreement with

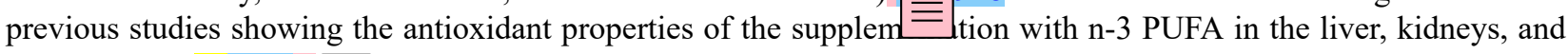
brain of rats [404243] $\equiv$ addition, the supplementations with extra virgin olive oil and n-3 PUFA are able to decrease the oxidative str $\equiv$-elated parameters in HFD-fed mice [2022374242] $\equiv$ this regard, specific n-3 fatty acid oxidation products, particularly isoprostanes, and extra virgin oil polyphenols $\mathrm{c}$ ead to the stabilization and activation of the $\mathrm{Nrf} 2$ transcription factor. Nrf2 activation provides antioxidant defense against oxidative stress [43-4543-4643-4643-46] $\equiv$ contrast to the beneficial effects of MUFA and n-3 PUFA on oxidative stress parameters, conjugated linoleic a (CLA), isomers of linoleic acid (n-6 PUFA), have been associated with the enhancement of oxidative stress markers, both non-enzymatic and enzymatic markers [46-5046-5146-5146-5146-5146-51] Furthermore, CLA supplementation fails to show beneficial effects on lipid peroxidation and antioxidant metabolism $\equiv$ in overweight/obese individuals [52,5251] $\equiv$ wever, other studies showed that the supplementation with CLA ameliorates oxidative stress in atherosclerotic 53 三 in non-alcoholic fatty liver disease (NAFLD) patients [53]

In conclusion, diet-induced obesity resulted in increased oxidative stress in the liver, lungs, and kidneys or mice. In turn, both supplementations with 2-OHOA as well as with EPA and DHA were able to restore the redox state in these organs, bringing the values to similar levels to those of non-DIO controls. Thus, these supplementations could be a promising nutritional strategy to reduce the progression of obesity-related diseases as well as to promote a healthy aging, probably through the reduction of oxidative stress. 
Acknowledgements

C.H. is the recipient of a PhD fellowship from CNP-q-Brazil.

\section{Disclosure statement}

No potential conflict of interest was reported by the author(s).

\section{References}

1. Alvarado C, Alvarez P, Jiménez L, et al. Oxidative stress in leukecytes from young prematurely aging mice is reversed by supplementation with biseuits rich in antioxidants. Dev Comp Immunol. 2006;30(12):1168 1180. Hariri N, Thibault L. High-fat diet-induced obesity in animal models. Nutr Res Rev. 2010;23(2):270 299.

1. AbdouProtective role of omega-3 polyunsaturated fatty acid against lead acetate-induced toxicity in liver and kidney of female rats HM, Hassan MA. Biomed Res Int. 2014;2014:435857. Hariri N, Thibault L. High-fat diet-induced obesity in animal models. Nutr Res Rev. 2010;23(2):270 299.

1. Hariri N, Thibault L. High-fat diet-induced obesity in animal models. Nutr Res Rev. 2010;23(2):270-299. doi:10.1017/S0954422410000168.

2. Hariri N, Thibault L. High-fat diet-induced obesity in animal models. Nutr Res Rev. 2010;23(2):270 299. doi:10.1017/S0954422410000168. Swinburn BA, Sacks G, Hall KD, et al. The global obesity pandemic: shaped by global drivers and local environments. Lancet. 2011;378(9793):804 814.

2. Swinburn B A, Sacks G, Hall K D, et al. The global obesity pandemic: shaped by global drivers and local environments. Lancet (London, England). Lancet. 2011;378(9793):804-814. doi:10.1016/S0140-6736(11)60813-1. 21872749

3. Hruby A, Hu F B. The Epidemiology of Obesity: A Big Picture. PharmacoEconomics. 2015;33(7):673-689. doi:10.1007/s40273-014-0243-x.

\section{4. de HerediaObesity, inflammation and the immune system FP, Gómez-Martínez S, Marcos $\Lambda$. . Proc Nutr Soc. 2012;71(2):332 338. Hruby A, Hu FB. The epidemiology of obesity: a big picture. Pharmacoeconomics. $2015 ; 33(7): 673-689$.}

4. Manna P, Jain S K. Obesity, Oxidative Stress, Adipose Tissue Dysfunction, and the Associated Health Risks: Causes and Therapeutic Strategies. Metabolic Syndrome and Related Disorders. 2015;13(10):423-444. doi:10.1089/ met.2015.0095.

5. De la Fuente M, Miquel J. An update of the oxidation inflammation theory of aging: the involvement of the immune system in oxi-inflamm-aging. Curr Pharm Des. 2009;15(26):3003 3026. Manna P, Jain SK. Obesity, oxidative stress, adipose tissue dysfunction, and the associated health risks: causes and therapeutic strategies. Metab Syndr Relat Disord. 2015;13(10):423 444.

5. Fiorentino T, Prioletta A, Zuo P, et al. Hyperglycemia-induced Oxidative Stress and its Role in Diabetes Mellitus Related Cardiovascular Diseases. CPD. 19(32):5695-5703. doi:10.2174/1381612811319320005.

6. De Pablo MA, Alvarez de Cienfuegos G. Modulatory effects of dietary lipids on immune system functions. Immunol Cell Biol. 2000;78(1):31 39. Fiorentino T, Prioletta A, Zuo P, et al. Hyperglycemia-induced Oxidative Stress and its Role in Diabetes Mellitus Related Cardiovaseular Diseases. CPD. 19(32):5695 5703.

6. Fiorentino T, Prioletta A, Zuo P, et al. Hyperglycemia induced Oxidative Stress and its Role in Diabetes Mellitus Related Cardiovascular Diseases. CPD. 19(32):5695 5703. doi:10.2174/1381612811319320005.

6. Heymsfield S B, Greenberg A S, Fujioka K, et al. Recombinant leptin for weight loss in obese and lean adults: a randomized, controlled, dose-escalation trial. JAMA. JAMA. 1999;282(16):1568-1575. doi:10.1001/ jama.282.16.1568. 10546697

7. Di Domenico M, Pinto F, Quagliuolo L, et al. The role of oxidative stress and hormones in controlling obesity. Front Endocrinol (Lausanne). 2019;10:540. Heymsfield SB, Greenberg AS, Fujioka K, et al. Recombinant leptin for weight loss in obese and lean adults: a randomized, controlled, dose-esealation trial. JAMA. 1999;282(16):1568 1575. 
7. Domenico $\mathrm{m} \mathrm{D}$, Pinto f Quagliuolo 1, et al. The role of oxidative stress and hormones in controlling obesity. Front Endocrinol (Lausanne). 2019;10(540)

8. Du S, Jin J, Fang W, et al. Does fish oil have an anti-obesity effect in overweight/obese adults? A meta-analysis of randomized controlled trials. PLoS One. 2015;10(11):e0142652. Di DomenicoM, Pinto F, Quaglinolo L, et al. The role of oxidative stress and hormenes in controlling obesity. Front Endocrinol (Lattsanne). 2019;10:540.

8. Ebrahimi Mameghani M, Scott JA, Der G, et al. Changes in weight and waist cireumference over 9 years in a Scottish population. Eur J Clin Nutr. 2008;62(10):1208 1214. Vincent HK, Powers SK, Dirks AJ, et al. Mechanism for obesity-induced inerease in myoeardial lipid peroxidation. Int J Obes. 2001;25(3):378 388.

8. Vincent HK, Powers SK, Dirks AJ, et al. Mechanism for obesity-induced increase in myocardial lipid peroxidation. Int J Obes. 2001;25(3):378-388. doi:10.1038/sj.ijo.0801536.

9. Trayhurn P. Hypoxia and adipose tissue function and dysfunction in obesity. Physiological Reviews. Physiol Rev. 2013;93(1):1-21. doi:10.1152/physrev.00017.2012. 23303904

10. Eftekhari MH, Aliasghari F, Babaei-Beigi M, et al. Effect of conjugated linoleic acid and omega- 3 fatty acid supplementation on inflammatory and oxidative stress markers in atheroselerotic patients. ARYA Atheroseler. 2013;9:311 318. Trayhurn P. Hypoxia and adipose tissue function and dysfunction in obesity. Physiol Rev. 2013;93(1):1 21.

10. Vincent HK, Powers SK, Dirks AJ, et al. Mechanism for obesity-induced increase in myocardial lipid peroxidation. Int J Obes. 2001;25(3):378 388. doi:10.1038/sj.ijo.0801536.

10. Fernández-Sánchez A, Madrigal-Santillán E, Bautista M, et al. Inflammation, oxidative stress, and obesity. Int J Mol Sci. 2011;12(5):3117-3132.

11. Fiorentino TV, Prioletta $\Lambda$, Zuo P, et al. Hyperglycemia induced oxidative stress and its role in diabetes mellitus related cardiovascular diseases. Curr Pharm Des. 2013;19(32):5695 5703. de HerediaFP, Gómez-Martínez S, Mareos A. Obesity, inflammation and the immune system. Proc Nutr Soc. 2012;71(2):332 338.

11. De Heredia F P, Gómez-Martínez S, Marcos A. Obesity, inflammation and the immune system. The Proceedings of the Nutrition Society. Proc Nutr Soc. 2012;71(2):332-338. doi:10.1017/S0029665112000092. 22429824

12. Freeman LR, Keller JN. Oxidative stress and cerebral endothelial cells: regulation of the blood brain-barrier and antioxidant based interventions. Biochim Biophys Acta. 2012;1822(5):822 829. Schieber M, Chandel NS. ROS function in redox signaling and oxidative stress. Curr Biol. 2014;24(10):R453 R462.

12. Schieber M, Chandel N. ROS Function in Redox Signaling and Oxidative Stress. Current Biology.

2014;24(10):R453-R462. doi:10.1016/j.cub.2014.03.034.

13. Gao L, Wang J, Sekhar KR, et al. Novel $n-3$ fatty acid oxidation products activate Nrf2 by destabilizing the assoeiation between Keap1 and Cullin3. J Biol Chem. 2007;282(4):2529 2537. Hunsche C, Hernandez O, Gheorghe A, et al. Immune dysfunetion and inereased oxidative stress state in diet-induced obese mice are reverted by nutritional supplementation with monounsaturated and n-3 polyunsaturated fatty acids. Eur J Nutr. 2018;57(3):1123 1135.

13. Hunsche $\mathrm{C}$, Hernandez $\mathrm{O}$, Gheorghe $\mathrm{A}$, et al. Immune dysfunction and increased oxidative stress state in dietinduced obese mice are reverted by nutritional supplementation with monounsaturated and $\mathrm{n}-3$ polyunsaturated fatty acids. Eur J Nutr. 2018;57(3):1123-1135. doi:10.1007/s00394-017-1395-1.

14. Gheorghe A, de Heredia FP, Hunsche C, et al. Oxidative stress and immunosenescence in spleen of obese mice ean be reversed by 2 -hydroxyoleic acid.. Exp Physiol. 2017;102(5):533 544 Martínez de Toda I, Vida C, Garrido A, et al. Redox parameters as markers of the rate of aging and predictors of life span. J Gerontol $\triangle$ Biol Sei Med Sei. 2020;75(4):613 620 .

14. Toda i M d, Vida c Garrido a, et al. Redox parameters as markers of the rate of aging and predictors of life span. J Gerontol A Biol Sci Med Sci. 2020;75(4):613

15. Hariri N, Thibault L. High-fat diet-induced obesity in animal models. Nutr Res Rev. 2010;23(2):270 299. De la Fuente M, Miquel J. An update of the oxidation inflammation theory of aging: the involvement of the immune system in oxi-inflamm-aging. Curr Pharm Des. 2009;15(26):3003 3026. 
15. Fuente M, Miquel J. An Update of the Oxidation-Inflammation Theory of Aging: The Involvement of the Immune System in Oxi-Inflamm-Aging. CPD. 15(26):3003-3026. doi:10.2174/138161209789058110.

\begin{abstract}
16. Hernández-Rodas MC, Valenzuela R, Echeverría F, et al. Supplementation with docosahexaenoic acid and extra virgin olive oil prevents liver steatosis indueed by a high-fat diet in mice through PPAR-a and Nrfz upregulation with concomitant SREBP 1c and NF kB downregulation. Mol Nutr Food Res. 2017;61(12):1700479. Hunsehe C, Hernandez $\Theta$, De la Fuente $M$. Impaired immune response in old mice suffering from obesity and premattre immmnoseneseenee in adulthood. J Gerontel $\triangle$ Biol Sei Med Sei. 2016;71(8):983 991.
\end{abstract}

16. Hunsche C, Hernandez O, De La Fuente M. Impaired Immune Response in Old Mice Suffering from Obesity and Premature Immunosenescence in Adulthood. The Journals of Gerontology. Series A, Biological Sciences and Medical Sciences. J Gerontol A Biol Sci Med Sci. 2016;71(8):983-991. doi:10.1093/gerona/glv082. 26219848

17. Heymsfield SB, Greenberg $\Lambda$ S, Fujioka K, et al. Recombinant leptin for weight loss in obese and lean adults: a randomized, controlled, dose-esealation trial. JAMA. 1999;282(16):1568 1575. Hunsehe C, Martínez de Toda I, De la FuenteM. Impacts of the late adulthood diet induced obesity onset on behavior, immune function, redox state and life span of male and female mice. Brain Behav Immun. 2019;78:65 77.

17. Hunsche C, De Toda I M, De La Fuente M. Impacts of the late adulthood diet-induced obesity onset on behavior, immune function, redox state and life span of male and female mice. Brain, Behavior, and Immunity. 2019;78:65-77. doi:10.1016/j.bbi.2019.01.010.

18. Hruby $\Lambda$, Hu FB. The epidemiology of obesity: a big picture. Pharmacoeconomies. 2015;33(7):673 689. Gheorghe $\Lambda$, de Heredia FP, HunscheC, et al. Oxidative stress and immunosenescence in spleen of obese mice ean be reversed by 2 -hydroxyoleic aeid. Exp Physiol. 2017;102(5):533 544.

18. Gheorghe A, Pérez De Heredia F, Hunsche C, et al. Oxidative stress and immunosenescence in spleen of obese mice can be reversed by 2-hydroxyoleic acid. Exp Physiol. 2017;102(5):533-544. doi:10.1113/EP086157.

19. Illesca P, Valenzuela R, Espinosa A, et al. Hydroxytyrosol supplementation ameliorates the metabolic disturbances in white adipose tissue from mice fed a high-fat diet through recovery of transcription factors Nrf2, SREBP-1c, PPAR- $\gamma$ and NF-KB. Biomed. Pharmacother. 2019;109:2472-2481. doi:10.1016/j.biopha.2018.11.120.

20. Hunsche $C$, Hernandez $O$, De la Fuente $M$. Impaired immune response in old mice suffering from obesity and premature immunosenescence in adulthood. J Gerontol $\triangle$ Biol Sci Med Sci. 2016;71(8):983 991. Illesea P, Valenzuela R, Espinosa A, et al. Hydroxytyrosol supplementation ameliorates the metabolic disturbances in white adipose tisste from mice fed a high-fat diet through recovery of transeription factors $\mathrm{Nrf2}$, SREBP-1e, PPAR- $\gamma$ and NF- $\mathrm{kB}$. Biemed Pharmacother. 2019;109:2472 2481.

20. Redondo Useros N, Gheorghe A, Perez De Heredia F, et al. 2-OHOA supplementation reduced adiposity and improved cardiometabolic risk to a greater extent than n-3 PUFA in obese mice. Obesity Research \& Clinical Practice. 2019;13(6):579-585. doi:10.1016/j.orcp.2019.10.009.

21. Hunsche $C$, Hernandez $\Theta$, Gheorghe $\Lambda$, et al. Immune dysfunction and increased oxidative stress state in dietinduced obese mice are reverted by nutritional supplementation with monounsaturated and $n-3$ polyunsaturated fatty acids. Eur J Nutr. 2018;57(3):1123 1135. Useros NR, Gheorghe A, de HerediaFP, et al. 2-OHOA supplementation reduced adiposity and improved cardiometabolic risk to a greater extent than 3-PUFA in obese mice. Obes Res Clin Pract. 2019; $13(6): 579-585$.

21. Valenzuela R, Espinosa A, Llanos P, et al. Anti-steatotic effects of an n-3 LCPUFA and extra virgin olive oil mixture in the liver of mice subjected to high-fat diet. Food Funct. 2016;7(1):140-150. doi:10.1039/C5FO01086A.

22. Hunsche C, Martínez de Toda I, De la Fuente M. Impacts of the late adulthood diet induced obesity onset on behavior, immune function, redox state and life span of male and female mice. Brain Behav Immun. 2019;78:65 77. Valenzuela R, Espinosa A, Llanos P, et al.Anti-steatotic effects of an n-3 LCPUFA and extra virgin olive oil mixture in the liver of mice subjected to high fat diet. Food Funct. 2016;7(1):140 150.

22. Valenzuela R, Illesca P, Echeverría F, et al. Molecular adaptations underlying the beneficial effects of hydroxytyrosol in the pathogenic alterations induced by a high-fat diet in mouse liver: PPAR- $\alpha$ and Nrf2 activation, and NFкB down-regulation. Food Funct. 2017;8(4):1526-1537. doi:10.1039/C7FO00090A. 
23. Illesea P, Valenzuela R, Espinosa A, et al. Hydroxytyrosol supplementation ameliorates the metabolic disturbanees in white adipose tisste from mice fed a high-fat diet through recovery of transeription faetors Nrf2, SREBP-1e, PPAR- $\gamma$ and NF-кB. Biomed Pharmacother. 2019;109:2472 2481. Valenzuela R, Hllesea P, EcheverríaF, et al. Molecular adaptations underlying the beneficial effects of hydroxytyrosol in the pathogenic alterations induced by a highfat diet in mouse liver: PPAR- $\alpha$ and Nrf2 activation, and NF- - BB down-regulation. Food Funct. 2017;8(4):1526 1537.

23. Rincón-Cervera M A, Valenzuela R, Hernandez-Rodas M C, et al. Supplementation with antioxidant-rich extra virgin olive oil prevents hepatic oxidative stress and reduction of desaturation capacity in mice fed a high-fat diet: Effects on fatty acid composition in liver and extrahepatic tissues. Nutrition. 2016;32(11-12):1254-1267. doi:10.1016/j.nut.2016.04.006.

24. Kim J, Paik HD, Shin MJ, et al. Eight weeks of conjugated linoleic acid supplementation has no effect on antioxidant status on healthy overweight/obese Korean individuals. Eur J Nutr. 2012;51(2):135 141. Rineón-Cervera MA, Valenzuela R, Hernandez RodasMC, et al. Supplementation with antioxidant rich extra virgin olive oil prevents hepatic oxidative stress and reduction of desaturation capacity in mice fed a high-fat diet: effects on fatty acid eomposition in liver and extrahepatic tissues. Nutrition. 2016;32(11 12):1254 1267.

24. Valenzuela R, Videla L A. The importance of the long-chain polyunsaturated fatty acid n-6/n-3 ratio in development of non-alcoholic fatty liver associated with obesity. Food Funct. 2011;2(11):644 doi:10.1039/c1 fo10133a.

25. Liu J, Hinkhouse MM, Sun W, et al. Redox regulation of panereatic cancer cell growth: role of glutathione per exidase in the suppression of the malignant phenotype. Hum Gene Ther. 2004;15(3):239 250. Valenzuela R, Videta $\mathrm{L} \Lambda$. The importance of the long-chain polyunsaturated fatty acid n-6/n-3 ratio in development of non-alcoholie fatty liver associated with obesity. Food Funct. 2011;2(11):644 648.

25. Valenzuela R, Barrera C, Espinosa A, et al. Reduction in the desaturation capacity of the liver in mice subjected to high fat diet: Relation to LCPUFA depletion in liver and extrahepatic tissues. Prostaglandins, Leukotrienes, and Essential Fatty Acids. Prostaglandins Leukot Essent Fatty Acids. 2015;98:7-14. doi:10.1016/j.plefa.2015.04.002. 25910408

26. Manna P, Jain SK. Obesity, oxidative stress, adipose tissue dysfunction, and the associated health risks: causes and therapeutic strategies. Metab Syndr Relat Disord. 2015;13(10):423 444. Valenzuela R, Barrera C, Espinosa $A$, et al.Reduction in the desaturation capacity of the liver in mice subjected to high fat diet: relation to LCPUFA depletion in liver and extrahepatic tissues. Prostaglandins Leukot Essent Fatty Acids. 2015:98:7 14.

26. Savini I, Catani M, Evangelista D, et al. Obesity-Associated Oxidative Stress: Strategies Finalized to Improve Redox State. IJMS. 2013;14(5):10497-10538. doi:10.3390/ijms140510497.

27. Martínez de Toda I, Vida C, Garrido A, et al. Redox parameters as markers of the rate of aging and predictors of life span. J Gerontol A Biol Sei Med Sei. 2020;75(4):613 620. Savini I, Catani MV, EvangelistaD, et al. Obesityassociated oxidative stress: strategies finalized to improve redox state. Int J Mol Sei. 2013;14(5):10497 10538.

27. De Pablo M A, Alvarez De Cienfuegos G. Modulatory effects of dietary lipids on immune system functions. Immunology and Cell Biology. Immunol Cell Biol. 2000;78(1):31-39. doi:10.1046/j.1440-1711.2000.00875.x. 10651927

28. Mujico JR, Bacean GC, Gheorghe $\Lambda$, et al. Changes in gut mierobiota due to supplemented fatty acids in dietindueed obese mice. Br J Nutr. 2013;110(4):711 720. De PabloMA, Alvarez de Cienfuegos G. Modulatory effects of dietary lipids on immune system functions. Immunol Cell Biol. 2000;78(1):31 39.

28. Surette M E. The science behind dietary omega-3 fatty acids. CMAJ : Canadian Medical Association Journal = Journal De L'association Medicale Canadienne. CMAJ. 2008;178(2):177-180. doi:10.1503/cmaj.071356. 18195292

29. Niture SK, Khatri R, Jaiswal AK. Regulation of Nrf2 an update. Free Radic Biol Med. 2014;66:36 44. SuretteME. The seience behind dietary omega-3 fatty acids. CMAJ. 2008;178(2):177 180.

29. Mujico J R, Baccan G C, Gheorghe A, et al. Changes in gut microbiota due to supplemented fatty acids in dietinduced obese mice. The British Journal of Nutrition. Br J Nutr. 2013;110(4):711-720. doi:10.1017/

S0007114512005612. 23302605 
30. Noeman SA, Hamooda HE, Baalash AA. Biochemical study of oxidative stress markers in the liver, kidney and heart of high fat diet induced obesity in rats. Diabetol Metab Syndr. 2011;3(1):17. MujicoJR, Bac-

ean $\mathrm{GC}$, Gheorghe $\mathrm{A}$, et al. Changes in gut mierobiota due to supplemented fatty acids in diet-induced obese mice. Br JNutr. 2013;110(4):711 720 .

30. Gheorghe A, Pérez De Heredia F, Hunsche C, et al. Oxidative stress and immunosenescence in spleen of obese mice can be reversed by 2 -hydroxyoleic acid. Exp Physiol. 2017;102(5):533 544. doi:10.1113/EP086157.

30. Alvarado C, Álvarez P, Jiménez L, et al. Oxidative stress in leukocytes from young prematurely aging mice is reversed by supplementation with biscuits rich in antioxidants. Dev. Comp. Immunol. 2006;30(12):1168-1180. doi:10.1016/j.dci.2006.03.004.

31. Patten AR, Brocardo PS, Christie BR. Omega 3 supplementation can restore glutathione levels and prevent oxi dative damage caused by prenatal ethanol exposure. J Nutr Biochem. 2013;24(5):760 769. AlvaradoC, Alvarez P, Jiménez $\mathrm{L}$, et al. Oxidative stress in leukecytes from young prematurely aging mice is reversed by supplementation with biscuits rich in antioxidants. Dev Comp Immunol. 2006;30(12):1168 1180.

31. Vögler O, López-Bellan A, Alemany R, et al. Structure-effect relation of C18 long-chain fatty acids in the reduction of body weight in rats. Int J Obes. 2008;32(3):464-473. doi:10.1038/sj.ijo.0803768.

32. Rincón-Cervera MA, Valenzuela R, Hernandez-Rodas MC, et al. Supplementation with antioxidant-rich extra virgin olive oil prevents hepatic oxidative stress and reduction of desaturation eapacity in mice fed a high-fat diet: effects on fatty acid composition in liver and extrahepatic tissues. Nutrition. 2016;32(11 12):1254 1267. V̈̈glerO, López-Bellan A, Alemany R, et al. Structure effect relation of C18 long-chain fatty acids in the reduction of body weight in rats. Int JObes (Lond). 2008;32(3):464 473.

32. Du S, Jin J, Fang W, et al. Does Fish Oil Have an Anti-Obesity Effect in Overweight/Obese Adults? A MetaAnalysis of Randomized Controlled Trials. PLoS ONE. 2015;10(11):e0142652 doi:10.1371/journal.pone.0142652.

33. Rindler PM, Plafker SM, Szweda LI, et al. High dietary fat selectively increases catalase expression within car diac mitochondria. J Biol Chem. 2013;288(3):1979 1990. DuS, Jin J, Fang W, et al. Does fish oil have an anti-obesity effect in overweight/obese adults? A meta-analysis of randomized controlled trials. PLoS One. 2015;10(11):e0142652.

33. Freeman L R, Keller J N. Oxidative stress and cerebral endothelial cells: regulation of the blood-brain-barrier and antioxidant based interventions. Biochimica Et Biophysica Acta. Biochim Biophys Acta. 2012;1822(5):822-829. doi:10.1016/j.bbadis.2011.12.009. 22206999

34. Risérus U, Basu S, Jovinge S, et al. Supplementation with conjugated linoleic acid causes isomer-dependent oxidative stress and elevated $C$ reactive protein: a potential link to fatty acid induced insulin resistance. Circulation. 2002;106(15):1925 1929. FreemanLR, Keller JN. Oxidative stress and cerebral endothelial cells: regulation of the blood brain-barrier and antioxidant based interventions. Biochim Biophys Acta. 2012;1822(5):822 829.

34. Noeman sa hamooda he, Baalash aa. Biochemical study of oxidative stress markers in the liver. kidney and heart of high fat diet induced obesity in rats. Diabetol Metab Syndr. 2011;3(1):17

35. Risérus U, Vessby B, Arnlöv J, et al. Effects of eis-9, trans-11 conjugated linoleic acid supplementation on insulin sensitivity, lipid peroxidation, and proinflammatory markers in obese men. Am J Clin Nutr. 2004;80(2):279 283. Noeman SA, Hamooda HE, Baalash AA. Biochemieal study of oxidative stress markers in the liver, kidney and heart of high fat diet induced obesity in rats. Diabetol Metab Syndr. 2011;3(1):17

35. Valenzuela R, Espinosa A, González-Mañán D, et al. N-3 Long-Chain Polyunsaturated Fatty Acid Supplementation Significantly Reduces Liver Oxidative Stress in High Fat Induced Steatosis. PLoS One. 2012;7(10):e46400 doi:10.1371/journal.pone.0046400.

36. I, Catani MV, Evangelista D, et al. Obesity-associated oxidative stress: strategies finalized to improve redox state. Int J Mol Sei. 2013;14(5):10497 10538. Valenzuela R, Espinosa A, González-Mañán D, et al. N-3 longehain polyunsaturated fatty acid supplementation significantly reduces liver oxidative stress in high fat induced steatosis. PLoS One. 2012;7(10):e46400. 
36. Yuzefovych L V, Musiyenko S I, Wilson G L, et al. Mitochondrial DNA Damage and Dysfunction, and Oxidative Stress Are Associated with Endoplasmic Reticulum Stress, Protein Degradation and Apoptosis in High Fat DietInduced Insulin Resistance Mice. PLoS One. 2013;8(1):e54059 doi:10.1371/journal.pone.0054059.

37. Schieber M, Chandel NS. ROS function in redox signaling and oxidative stress. Curr Biol. 2014;24(10):R453 R462. YuzeforychLV, Musiyenko SI, Wilson GL, et al. Mitochondrial DNA damage and dysfunction, and oxidative stress are associated with endoplasmic reticulum stress, protein degradation and apoptosis in high fat diet-induced insulin resistance mice. PLoS One. 2013;8(1):e54059.

37. Rindler P M, Plafker S M, Szweda L I, et al. High dietary fat selectively increases catalase expression within cardiac mitochondria. The Journal of Biological Chemistry. J Biol Chem. 2013;288(3):1979-1990. doi:10.1074/ jbc.M112.412890. 23204527

38. Smedman A, Basu S, Jovinge S, et al. Conjugated linoleic acid increased C-reactive protein in human subjects. Br J Nutr. 2005;94(5):791 795. RindlerPM, Plafker SM, Szweda LI, et al. High dietary fat selectively inereases eatatase expression within cardiac mitochondria. J Biol Chem. 2013;288(3):1979 1990.

38. Yan H, Harding J J. Glycation-induced inactivation and loss of antigenicity of catalase and superoxide dismutase. Biochemical Journal. 1997;328(2):599-605. doi:10.1042/bj3280599.

39. Liu J, Hinkhouse M M, Sun W, et al. Redox Regulation of Pancreatic Cancer Cell Growth: Role of Glutathione Peroxidase in the Suppression of the Malignant Phenotype. Hum. Gene Ther. 2004;15(3):239-250. doi:10.1089/104303404322886093.

40. Smedman A, Vessby B, Basu S. Isomer specific effects of conjugated linoleic acid on lipid peroxidation in humans: regulation by alpha-tocopherol and cyclo-oxygenase-2 inhibitor. Clin Sci. 2004;106(1):67 73. LiuJ, Hinkhouse MM, Sun W, et al. Redox regulation of pancreatic cancer cell growth: role of glutathione peroxidase in the suppression of the malignant phenotype. Hum Gene Ther. 2004;15(3):239 250.

41. Surette ME. The seience behind dietary omega 3 fatty acids. CMAJ. 2008;178(2):177 180. YanH, Har ding JJ. Glycation-induced inactivation and loss of antigenicity of catalase and superoxide dismutase. Biochem J. 1997;328(2):599-605.

40. Abdou H M, Hassan M A. Protective Role of Omega-3 Polyunsaturated Fatty Acid against Lead Acetate-Induced Toxicity in Liver and Kidney of Female Rats. Biomed Res. Int. 2014;2014:1-11. doi:10.1155/2014/435857.

41. Swinburn BA, Sacks G, Hall KD, et al. The global obesity pandemic: shaped by global drivers and local environ ments. Lancet. 2011;378(9793):804 814. AbdouHM, Hassan MA. Protective role of omega-3 polyunsaturated fatty acid against lead acetate-induced toxicity in liver and kidney of female rats. Biomed Res Int. 2014;2014:435857.

41. Patten A R, Brocardo P S, Christie B R. Omega-3 supplementation can restore glutathione levels and prevent oxidative damage caused by prenatal ethanol exposure. The Journal of Nutritional Biochemistry. 2013;24(5):760769. doi:10.1016/j.jnutbio.2012.04.003.

42. Trayhurn P. Hypoxia and adipose tissue function and dysfunction in obesity. Physiol Rev. 2013;93(1):1 21. PattenAR, Broeardo PS, Christie BR. Omega-3 supplementation ean restore glutathione levels and prevent oxidative damage caused by prenatal ethanol exposure. J Nutr Biochem. 2013;24(5):760 769.

42. Hernández-rodas M C, Valenzuela R, Echeverría F, et al. Supplementation with Docosahexaenoic Acid and Extra Virgin Olive Oil Prevents Liver Steatosis Induced by a High-Fat Diet in Mice through PPAR- $\alpha$ and Nrf2 Upregulation with Concomitant SREBP-1c and NF-kB Downregulation. Mol Nutr Food Res. 2017;61(12):1700479 doi:10.1002/mnfr.201700479.

43. Turpeinen AM, Ylönen N, Willebrand EV, et al. Immunologieal and metabolic effects of eis-9, trans-11-conjugated linoleic aeid in subjects with birch pollen allergy. Br J Nutr. 2008;100(1):112 119. Hernández RodasMC, Valenzuela R, Echeverría F, et al. Supplementation with docosahexaenoic acid and extra virgin olive oil prevents liver steatosis induced by a high-fat diet in mice through PPAR- $\alpha$ and Nrf2 upregulation with concomitant SREBP-1e and NFkB downregulation. Mol Nutr Food Res. 2017;61(12):1700479. 
43. Gao L, Wang J, Sekhar K R, et al. Novel n-3 Fatty Acid Oxidation Products Activate Nrf2 by Destabilizing the Association between Keap1 and Cullin3. J Biol Chem. 2007;282(4):2529-2537. doi:10.1074/jbc.M607622200.

44. Useros NR, Gheorghe $\Lambda$, de Heredia FP, et al. 2-OHOA supplementation reduced adiposity and improved eardiemetabolie risk to a greater extent than 3-PUFA in obese mice. Obes Res Clin Pract. 2019;13(6):579-

585. GroL, Wang J, Sekhar KR, et al. Novel n 3 fatty acid oxidation products activate Nrf2 by destabilizing the assoeiation between Keapl and Cullin3. J Biol Chem. 2007;282(4):2529 2537.

44. Niture S K, Khatri R, Jaiswal A K. Regulation of Nrf2 — an update. Free Radical Biol. Med. 2014;66:36-44. doi:10.1016/j.freeradbiomed.2013.02.008.

45. Valenzuela R, Barrera C, Espinosa A, et al. Reduetion in the desaturation eapacity of the liver in mice subjected to high fat diet: relation to LCPUFA depletion in liver and extrahepatic tisstes. Prostaglandins Leukot Essent Fatty Acids. 2015;98:7 14. NitureSK, Khatri R, Jaiswal AK. Regulation of Nrf2 an update. Free Radic Biol Med. 2014;66:36 44.

45. Risérus U, Basu S, Jovinge S, et al. Supplementation With Conjugated Linoleic Acid Causes Isomer-Dependent Oxidative Stress and Elevated C-Reactive Protein. Circulation. 2002;106(15):1925-1929.

doi:10.1161/01.CIR.0000033589.15413.48.

46. Valenzuela R, Espinosa $\Lambda$, Llanos $P$, et al. Anti-steatotic effects of an $n-3$ LCPUF $\Lambda$ and extra virgin olive oil mixture in the liver of mice subjected to high-fat diet. Food Funet. 2016;7(1):140 150. RisérusU, Basu S, Jovinge $S$, et al. Supplementation with conjugated linoleic acid causes isomer dependent oxidative stress and elevated C-reactive protein: a potential link to fatty acid-induced insulin resistance. Circulation. 2002;106(15):1925 1929.

46. Risérus U, Vessby B, Ärnlöv J, et al. Effects of cis-9,trans-11 conjugated linoleic acid supplementation on insulin sensitivity, lipid peroxidation, and proinflammatory markers in obese men. The American Journal of Clinical Nutrition. 2004;80(2):279-283. doi:10.1093/ajcn/80.2.279.

47. Valenzuela R, Espinosa $\Lambda$, González Mañán D, et al. N 3 long chain polyunsaturated fatty acid supplementation significantly reduces liver oxidative stress in high fat induced steatosis. PLoS One. 2012;7(10):e46400. RisérusU, Vessby B, Arnlöv J, et al. Effects of eis-9, trans-11 conjugated linoleic aeid supplementation on insulin sensitivity, lipid peroxidation, and proinflammatory markers in obese men. Am J Clin Nutr. 2004;80(2):279 283.

47. Smedman A, Basu S, Jovinge S, et al. Conjugated linoleic acid increased C-reactive protein in human subjects. The British Journal of Nutrition. Br J Nutr. 2005;94(5):791-795. doi:10.1079/bjn20041419. 16277783

48. Valenzuela R, Illesca P, Echeverría F, et al. Molecular adaptations underlying the beneficial effects of hydroxytyrosol in the pathogenic alterations induced by a high-fat diet in mouse liver: PPAR- $a$ and Nrf2 activation, and NFkB down regulation. Food Funet. 2017;8(4):1526 1537. SmedmanA, Basu S, Jovinge S, et al. Conjugated linoleie acid increased C-reactive protein in human subjects. Br J Nutr. 2005;94(5):791 795.

48. Smedman A, Vessby B, Basu S. Isomer-specific effects of conjugated linoleic acid on lipid peroxidation in humans: regulation by alpha-tocopherol and cyclo-oxygenase-2 inhibitor. Clinical Science (London, England : 1979). Clin Sci (Lond). 2004;106(1):67-73. doi:10.1042/CS20030105. 12956622

49. Valenzuela $R$, Videla $L \Lambda$. The importanee of the long - chain polyunsaturated fatty acid $n-6 / n-3$ ratio in development of non aleoholic fatty liver associated with obesity. Food Funct. 2011;2(11):644 648. SmedmanA, Vessby B, Basu S. Isomer-specific effeets of conjugated linoleic aeid on lipid peroxidation in humans: regulation by alpha-tocopherol and eyclo-oxygenase-2 inhibitor. Clin Sei. 2004;106(1):67 73.

49. Turpeinen A M, Ylönen N, Von Willebrand E, et al. Immunological and metabolic effects of cis-9, trans-11-conjugated linoleic acid in subjects with birch pollen allergy. Br J Nutr. 2008;100(1):112-119. doi:10.1017/ S0007114507886326.

50. Vineent HK, Powers SK, Dirks AJ, et al. Mechanism for obesity-induced inerease in myoeardial lipid peroxidation. Int J Obes. 2001;25(3):378 388. TurpeinenAM, Ylönen N, Willebrand EV, et al. Immtnologieal and metabolie effects of cis -9, trans 11 conjugated linoleic acid in subjects with birch pollen allergy. Br J Nutr. 2008;100(1):112 119. 
50. Kim J, Paik H-D, Shin M-J, et al. Eight weeks of conjugated linoleic acid supplementation has no effect on antioxidant status in healthy overweight/obese Korean individuals. Eur J Nutr. 2012;51(2):135-141. doi:10.1007/

s00394-011-0199-y.

51. Vögler $O$, López-Bellan $A$, Alemany $R$, et al. Strueture effect relation of $C 18$ long-chain fatty acids in the reduction of body weight in rats. Int J Obes (Lond). 2008;32(3):464 473. KimJ, Paik HD, Shin MJ, et al. Eight weeks of eonjugated linoleic acid supplementation has no effect on antioxidant status on healthy overweight/obese Korean individuals. Eur J Nutr. 2012;51(2):135 141.

51. Eftekhari mh Aliasghari $\mathrm{f}$ Babaei-Beigi $\mathrm{m}$, et al. Effect of conjugated linoleic acid and omega-3 fatty acid supplementation on inflammatory and oxidative stress markers in atherosclerotic patients. ARYA Atheroscler. 2013;9:311

52. Yan H, Harding J. Glycation induced inactivation and loss of antigenicity of catalase and superoxide dismutase. Biochem J. 1997;328(2):599 605. EftekhariMH, Aliasghari F, Babaei-Beigi M, et al. Effect of conjugated linoleic acid and omega-3 fatty acid supplementation on inflammatory and oxidative stress markers in atheroselerotic patients. ARYA Atheroseler. 2013;9:311 318.

52. Ebrahimi-Mameghani M, Scott J A, Der G, et al. Changes in weight and waist circumference over 9 years in a Scottish population. Eur J Clin Nutr. 2008;62(10):1208-1214. doi:10.1038/sj.ejcn.1602839.

53. Yuzefovych LV, Musiyenko SI, Wilson GL, et al. Mitochondrial DNA damage and dysfunction, and oxidative stress are associated with endoplasmic reticulum stress, protein degradation and apoptosis in high fat diet-induced insulin resistance mice. PLoS One. 2013;8(1):e54059. EftekhariMH, Aliasghari F, Babaei Beigi M, et al. Effect of conjugated linoleic acid and omega-3 fatty acid supplementation on inflammatory and oxidative stress markers in atheroselerotic patients. ARYA Atheroseler. 2013;9:311 318.

\section{AUTHOR QUERIES}

Query: AQ0: Please review the table of contributors below and confirm that the first and last names are structured correctly and that the authors are listed in the correct order of contribution. This check is to ensure that your names will appear correctly online and when the article is indexed.

\begin{tabular}{|c|c|c|c|}
\hline Sequence & Prefix Given name(s) & Surname & Suffix \\
\hline 1 & Caroline & Hunsche & \\
\hline 2 & Irene & Martínez de Toda & \\
\hline 3 & Oskarina & Hernandez & \\
\hline 4 & Beatriz & Jiménez & \\
\hline 5 & Ligia Esperanza & Díaz & \\
\hline 6 & Ascensión & Marcos & \\
\hline 7 & Mónica & De la Fuente & \\
\hline
\end{tabular}

Author Response: Ok

Query: AQ1: Please check whether the affiliations have been typeset correctly, and correct if inaccurate. Author Response: Ok

\section{Comments}

C1 Author: [1,2];

C2 Author: [3];

C3 Author: [4];

C4 Author: [5]; 
C5 Author: [6];

C6 Author: [7];

C7 Author: [8];

C8 Author: [9];

C9 Author: [13,16-22];

C10 Author: [16,19,21-23];

C11 Author: [23-25];

C12 Author: [26];

C13 Author: [27,28];

C14 Author: [20];

C15 Author: $[13,18]$;

C16 Author: [15];

C17 Author: [29];

C18 Author: [30];

C19 Author: [30];

C20 Author: $[13,18]$;

C21 Author: [13,16-18,20];

C22 Author: [31];

C23 Author: [20];

C24 Author: [26];

C25 Author: [33];

C26 Author: [34-36];

C27 Author: [19,33-36];

C28 Author: $[19,22]$;

C29 Author: [8];

C30 Author: [17];

C31 Author: [38,39];

C32 Author: $[13,18]$;

C33 Author: [40,41];

C34 Author: $[19,21,34,42]$;

C35 Author: [41,43,44];

C36 Author: [45-49];

C37 Author: [50];

C38 Author: [51,52]; 